\title{
Monoclonal Antibodies as Tools to Combat Fungal Infections
}

\author{
Sebastian Ulrich (1) and Frank Ebel * \\ Institute for Infectious Diseases and Zoonoses, Faculty of Veterinary Medicine, Ludwig-Maximilians-University, \\ D-80539 Munich, Germany; s.ulrich@lmu.de \\ * Correspondence: frank.ebel@lmu.de
}

Received: 26 November 2019; Accepted: 31 January 2020; Published: 4 February 2020

\begin{abstract}
Antibodies represent an important element in the adaptive immune response and a major tool to eliminate microbial pathogens. For many bacterial and viral infections, efficient vaccines exist, but not for fungal pathogens. For a long time, antibodies have been assumed to be of minor importance for a successful clearance of fungal infections; however this perception has been challenged by a large number of studies over the last three decades. In this review, we focus on the potential therapeutic and prophylactic use of monoclonal antibodies. Since systemic mycoses normally occur in severely immunocompromised patients, a passive immunization using monoclonal antibodies is a promising approach to directly attack the fungal pathogen and/or to activate and strengthen the residual antifungal immune response in these patients.
\end{abstract}

Keywords: monoclonal antibodies; invasive fungal infections; therapy; prophylaxis; opsonization

\section{Introduction}

Fungal pathogens represent a major threat for immunocompromised individuals [1]. Mortality rates associated with deep mycoses are generally high, reflecting shortcomings in diagnostics as well as limited and often insufficient treatment options. Apart from the development of novel antifungal agents, it is a promising approach to activate antimicrobial mechanisms employed by the immune system to eliminate microbial intruders. Antibodies represent a major tool to mark and combat microbes. Moreover, monoclonal antibodies (mAbs) are highly specific reagents that opened new avenues for the treatment of cancer and other diseases. This review provides an overview on studies in which $\mathrm{mAbs}$ have been used to combat experimental fungal infections caused by pathogenic yeasts, (Candida, Cryptococcus), dimorphic fungi (Histoplasma, Paracoccidioides, Sporothrix), or molds (Aspergillus, Rhizopus, Scedosporium).

\section{Elimination of Microbial Pathogens by Antibody-Dependent Mechanisms}

The antibody-antigen binding is a highly specific interaction that can directly modulate the biological activity of a target molecule, e.g., by neutralization of a toxin. Apart from secreted molecules, antibodies can also inhibit microbial surface proteins, such as adhesins or surface-bound enzymes. Surface-reactive antibodies can furthermore act as opsonins and thereby mark microbes out for destruction. Fc $\gamma$ receptors reside in the cytoplasmic membrane of phagocytes and recognize bound IgGs. In concert with the parallel recognition of conserved microbial structures by dedicated pattern recognition receptors, this boosts phagocytosis, enhances phagosome-lysosome fusion, and results in a more efficient microbial killing [2]. Bound IgM or IgG can furthermore recruit complement proteins to activate this part of the innate immune response resulting in an enhanced C3 receptor-mediated phagocytosis. Moreover, antibodies can have a catalytic activity; as exemplarily shown by Bowen et al. [3]: Two mAbs directed against glucuronoxylomannan (GXM) the major 
component of the Cryptococcus capsule were shown to possess a proteolytic activity and one of them was additionally able to cleave the GXM oligosaccharide. A major advantage of this mode of action is that catalytic antibodies can directly harm their target organism and therefore act independently of other elements of the immune system.

\section{The Cell Wall as Primary Target Structure for Antifungal Antibodies}

Antigens must be accessible for antibodies; surface-bound molecules and secreted proteins are therefore particular suitable target molecules. In contrast to plant-pathogenic fungi, dedicated virulence factors are rare in fungi causing systemic mycoses in mammals. Structural components like the capsule of Cryptococcus neoformans or general attributes like the dimorphism of Candida albicans clearly contribute to pathogenicity, but hardly any proteins are known that specifically attack host cells or highjack parts of the host cellular machinery. Although pathogenic fungi release a plethora of proteases, lipases, and other enzymes, these proteins seem to be of limited importance for the virulence of most human-pathogenic fungi. Consequently, the vast majority of protective antibodies described so far recognize surface bound antigens.

After binding to surface antigens, antibodies can act as opsonins to boost the phagocytic activity of immune cells. The fungal cell wall represents the most important target structure for opsonizing antibodies; it contains proteins, but consists mainly of carbohydrate polymers. Due to the lack of appropriate $\mathrm{T}$ cell responses, most antibodies directed against carbohydrate antigens belong to the IgM class that cannot interact with Fc $\gamma$-receptors, but this drawback can be experimentally overcome by coupling glycoantigens to a carrier protein. A particular problem to the immune response is the ability of many fungi to switch between different morphotypes, since many antigens are expressed in a morphotype-specific pattern. Consequently, the immune system needs to employ multiple receptors and mechanisms to combat and eliminate these pathogens. Phagocytosis is a major antimicrobial mechanism, but phagocytes have a limited capacity with respect to the size of their pray. This poses another problem, but only for certain fungal morphotypes: Yeasts and other single cells are taken-up easily, while hyphae are protected simply by their size.

\section{Protective Antibodies against Cryptococcus neoformans}

Cryptococcus neoformans is a major yeast pathogen that is unique among medically important fungi in its possession of a polysaccharide capsule. While infections of healthy individuals usually remain asymptomatic, hosts with a severely impaired cellular immunity can develop life-threatening, disseminated infections and meningitis. In contrast to C. albicans, Cryptococcus does not form hyphae during infection making it a seemingly easier target for an antibody-based therapy.

The Cryptococcus polysaccharide capsule is a crucial virulence determinant with GXM being its major component. As for certain bacteria, the capsule prevents recognition by pathogen recognition receptors and thereby protects the fungus from phagocytes. However, as for capsulated bacteria, this can be overcome by antibody-mediated opsonization.

The first report of a mAb providing protection against experimental cryptococcosis dates back to 1987 [4]. In this pioneering study, Dromer and co-workers used a GXM-specific IgG $_{1}$. Several years later, a similar protective activity was reported for a GXM-specific IgM [5]. Several studies directly compared GXM-specific mAbs belonging to different (sub)classes (Table 1A). The IgG 3 subtype turned out to be less protective or even deleterious, whereas mice immunized by administration of $\operatorname{IgG}_{1}, \operatorname{IgA}$ or IgM antibodies showed an improved outcome [6,7]. In vitro experiments revealed no difference in the opsonizing activity of the different isotypes [8]. Yuan et al. provided evidence that the $\mathrm{IgG}_{1}$-mediated protection and the deleterious effect of $\mathrm{IgG}_{3}$ depend on $\mathrm{CD} 4^{+}$- and $\mathrm{CD} 8^{+}-\mathrm{T}$ cells, respectively [9]. A non-protective $\mathrm{IgG}_{3}$ could be converted into a protective $\mathrm{IgG}_{1}$ by isotype switching, indicating that the $\mathrm{IgG}_{3}$ subclass is a crucial determinant in this context [10]. Further studies implicated distinct Fc $\gamma$-receptor functions [6], the genetic background of the infected mice [11], and 
distinct catalytic activities [3] in the strikingly different biological activities of these GMX-specific $\operatorname{IgG}_{1}$ and $\mathrm{IgG}_{3}$ switch variants.

IgM antibodies to GMX can be either protective or non-protective, which depends on a variety of factors, e.g., the route of infection, the size of the inoculum, the amount of mAbs administered, and the ability of these antibodies to promote phagocytosis [12]. Further studies showed that protection requires binding to certain GXM epitopes [13-15]. Shapiro et al. showed that protection mediated by GXM-specific IgM antibodies is independent of complement component $\mathrm{C} 3$ indicating that complement fixation is not required [16].

Remarkably, high GXM-specific titers can also cause deleterious effects in mice and this was attributed to the formation of antibody-antigen complexes. Depending on the antibody titer and the inoculum, this antibody-mediated acute lethal toxicity (ALT) can be induced by different IgG subclasses [17]. Cryptoccoccus infections are often chronic and released capsular polysaccharides can accumulate to very high levels in tissue and serum. Antibody induced ALT depends on the antigen concentration in the blood and the isotype of the antibody. Data of two groups indicate that $\operatorname{IgG}_{1}$, $\operatorname{IgG}_{2 a}$, and $\operatorname{IgG}_{2 b}$ can be deleterious, while $\operatorname{IgG}_{3}, \operatorname{IgM}$, and $\operatorname{IgA}$ lack this harmful activity $[18,19]$. ALT is triggered by the murine $\mathrm{IgG}_{1} 2 \mathrm{H} 1$, but is not induced by a mouse-human chimeric $\operatorname{IgG}_{2}$ derived from $2 \mathrm{H} 1$ suggesting that $\mathrm{Fc} \gamma$-receptor binding is crucial for this toxic effect [20].

\section{Protective Antibodies against Candida albicans}

The first evidence that antibodies are important during candidiasis came from the finding that patients who survived systemic infections developed strong antibody responses to certain C. albicans proteins, whereas patients who succumbed to infection had no, minor or fading responses [21]. An immunodominant $45 \mathrm{kDa}$ polypeptide was described and later on identified as a fragment of the heat shock protein Hsp90 [22]. Hsp90 is a highly conserved ATP-dependent molecular chaperone that stabilizes other molecules, governs morphogenesis, and is regarded as a key regulator of Candida virulence traits [23]. An IgG raised against C. albicans Hsp90 was the first mAb that was successfully tested in a murine model of systemic candidiasis [24]. Based on this murine immunoglobulin, a humanized, single chain antibody was developed, initially designated Efungumab, but later on renamed to Mycograb. This recombinant antibody is assumed to inhibit Hsp90 activity by binding to a central domain of Hsp90 that is responsible for the conformational change triggered by ATP binding [25]. Hsp90 is normally cytoplasmic, but to a certain extent, also a surface-bound protein [26]. It plays an important role in several stress responses including those triggered by antifungals. Accordingly, in vitro studies demonstrated a synergistic activity of Mycograb and antifungals, such as fluconazole, caspofungin, and amphotericin B. A clinical trial revealed that Mycograb plus lipid-associated amphotericin B produced significant clinical improvement for patients suffering from invasive candidiasis [27], but despite these promising results, marketing authorization was disapproved by the European Medicines Agency in 2017 based on concerns that the benefits of this treatment do not outweigh its risks.

A different approach was taken by Torrosantucci et al. [28], who coupled the $\beta$-glucan laminarin to the diphtheria toxoid and obtained polyclonal antibodies that defended mice against infections caused by $C$. albicans or A. fumigatus. A monoclonal $\beta$-glucan specific IgG2b antibody obtained by this approach and designated 2G8 turned out to be protective against $C$. albicans, A. fumigatus, and C. neoformans infections $[29,30]$. Remarkably, an IgM harboring the same complementarity-determining region as 2G8 was not protective [30]. Further experiments revealed that the IgG2b was highly specific for $\beta$-1,3-glucan and showed a much stronger reactivity with $\beta$-glucan molecules that are released by C. albicans than the corresponding IgM. These distinct specificities may explain the strikingly different protective potential of both antibodies. Interestingly, the $\operatorname{IgG}_{2 b}$ was also reported to inhibit growth of $C$. albicans and $A$. fumigatus in vitro, but the precise mode of action was not determined. More recently, a mouse-human chimera and a scFv-Fc derived from 2G8 were shown to promote killing of C. albicans by isolated neutrophils and to protect mice in a vulvovaginal model of infection [31]. In 
2019, Matveev et al. reported that an $\operatorname{IgG}_{1}$ specific for $\beta$-1,3-glucan delayed germination of A. fumigatus conidia and improved survival of mice infected with $C$. albicans via the intravenous route [32].

In a series of papers, Han, Cutler, and colleagues characterized two IgM mAbs directed against different $C$. albicans cell wall components. In immunofluorescence, both antibodies recognized the yeast, but not the hyphal form. B6.1, which is specific for $\beta$-1,2-linked mannotriose, stained Candida yeast cells more homogenously than B6 [33]. Both B6.1 and B6 protected mice against vaginal C. albicans infections [34], whereas only B6.1 provided protection in a model of disseminated candidiasis [35]. An $\mathrm{IgG}_{3} \mathrm{mAb}$ also recognizing $\beta$-1,2-linked mannotriose was later on shown to be protective in both the disseminated and the vaginal infection model and this was attributed to the strong complement binding mediated by $\mathrm{IgG}_{3}$ immunoglobulins [36].

Using a mannan-specific humanized $\operatorname{IgG}_{1}$ antibody, Zhang et al. observed enhanced phagocytosis of C. albicans by murine macrophages, increased deposition of complement component C3, and protection of mice from an otherwise lethal dose of C. albicans yeast cells [37]. Moreover, generation of recombinant switch variants of this antibody revealed that an $\operatorname{IgG}_{2}$ variant was less protective than the corresponding $\operatorname{IgG}_{1}, \operatorname{IgG}_{3}$, or $\operatorname{IgG}_{4}$ immunoglobulins [38].

A fully humanized $\mathrm{IgG}_{1}$ specific for $\beta$-1,6-linked poly-N-acetyl-D-glucosamine, a capsular antigen of several bacterial pathogens, cross-reacts with C. albicans and protected mice in a Candida keratitis model [39]. Kavishwar and Shukla described another protective antibody that belongs to the IgA isotype and binds to glycosyl moieties of C. albicans proteins [40].

Several other studies analyzed the impact of antibodies directed against different Candida surface proteins. In these experiments, $\operatorname{IgG}_{1}, \mathrm{IgG}_{3}$, and $\mathrm{IgM}$ mAbs provided protection in different models of infection [41-44]. One of these mAbs, designated C7, is directed against the Als3 mannoprotein, which has multiple functions, e.g., as an adhesin and invasin [45]. In vitro studies with this IgM demonstrated a direct growth inhibitory activity [46] that was later on attributed to an antibody-mediated inhibition of fungal iron acquisition [47].

Polyclonal rabbit antibodies directed against the surface-bound Hyr1 protein of C. albicans were also shown to be protective in a murine model of infection [48] and more recently, Rudkin et al. characterized several recombinant $\operatorname{IgG}_{1}$ mAbs specific for Hyr1 and other C. albicans surface molecules that were derived from $B$ cells isolated from human patients [49]. These mAbs enhanced phagocytosis of $C$. albicans yeasts and short hyphae by murine macrophages and protected mice from a systemic C. albicans infection. Probably, these human $\mathrm{IgG}_{1}$ antibodies interact with murine Fc $\gamma$ receptors and thereby boost the antifungal activities of macrophages and neutrophils. While the Hyr1-specific antibodies recognized exclusively $C$. albicans, the mAbs directed against other surface proteins were also reactive with other members of the genus Candida and may therefore possess a broader therapeutic potential [49].

The minor role of secreted proteins in fungal virulence in mammals has been mentioned above. However, de Bernardis et al. showed that antibodies against the secreted aspartic protease Sap2 are protective in a rat model of vaginitis, thereby demonstrating that protection is not restricted to mAbs directed to surface antigens [41]. Since Sap2 plays an important role in vaginal infections caused by C. albicans [50], it is conceivable that the protective activity of this mAb is due to inhibition of the proteolytic activity of Sap2.

Killer toxins (KTs) have been described for Saccharomyces spp., Pichia spp., and other non-pathogenic yeasts. These short, secreted proteins bind to the surface of sensitive fungi and kill them through different effector mechanisms [51]. According to the concept of anti-idiotypic antibodies, an antibody raised against an immunoglobulin specific for the active site of a particular enzyme can possess the enzymatic activity of this enzyme. Using this approach, anti-idiotypic recombinant antibodies were generated that mimic the antifungal activity of a KT derived from Wyckerhamomyces anomalus (formerly Pichia anomala). This recombinant antibody killed C. albicans in vitro and provided protection in a rat model of C. albicans vaginitis [52]. Interesting features of KT-like antibodies are their direct antifungal activity and their target structures that are often conserved in many fungal pathogens. 
Table 1. (A) Protective and non-protective mAbs against Cryptococcus neoformans. (B) Protective and non-protective mAbs against Candida albicans. (C) Protective and non-protective $\mathrm{mAbs}$ against dimorphic fungi. (D) Protective and non-protective mAbs against molds.

(A)

\begin{tabular}{|c|c|c|c|c|c|}
\hline Antigen & Infection Model & Application of $\mathrm{mAbs} \#$ & Protective & Non-Protective & Reference \\
\hline GXM & m., i.v. & i.p./24 h/10-100 $\mu \mathrm{g}$ & $\operatorname{IgG}_{1}$ & & [4] \\
\hline capsular polysaccharide & m., i.v. & $\begin{array}{l}\text { i.p./ }-24 \mathrm{~h} / 1 \mathrm{mg} \\
\text { i.p. } / 48 \mathrm{~h}+96 \mathrm{~h} / 500 \mu \mathrm{g}\end{array}$ & & $\begin{array}{l}\mathrm{IgG}_{1} *, \mathrm{IgG}_{2 \mathrm{a}}, \mathrm{IgG}_{2 \mathrm{~b}} \text { * } \\
\mathrm{IgG}_{1} * \mathrm{IgG}_{2}, \mathrm{IgG}_{2 \mathrm{~b}}\end{array}$ & {$[53]$} \\
\hline GXM & m., i.p. & i.p. $/ 0 \mathrm{~h} / 1 \mathrm{mg}$ & $\operatorname{Ig} A, \operatorname{IgG}_{1}>\operatorname{IgM}>\operatorname{IgG}_{3}$ & & [7] \\
\hline GXM & m., i.v. & i.p. $/-4 \mathrm{~h} / 1 \mathrm{mg}$ & $\operatorname{chIgG}_{1}$ & & [54] \\
\hline GXM & m., i.p. & i.p. $/-15 \mathrm{~min} / 1 \mathrm{mg}$ & two IgM & one IgM & {$[13]$} \\
\hline GXM & m., i.v. & i.p./-24 h/1 mg & $\mathrm{IgG}_{1}, \mathrm{IgG}_{2 \mathrm{~b}}, \mathrm{IgG}_{2 \mathrm{a}}>\mathrm{IgG}_{3}$ & & [6] \\
\hline GXM & m., i.v. & preincubation of yeasts with $\mathrm{mAb}$ & hIgM & & [5] \\
\hline melanin & m., i.v. & i.v. $/-30 \mathrm{~min} / 1 \mathrm{mg}$ & $\operatorname{IgM}$ & & {$[55]$} \\
\hline GXM & $\begin{array}{l}\text { m., i.v. } \\
\text { m., i.p. } \\
\text { m., i.t. }\end{array}$ & $\begin{array}{l}\text { i.p. } /-5,-30 \mathrm{~min} / 0.1,0.5 \text { or } 1 \mathrm{mg} \\
\text { i.p./ }-5,-30 \mathrm{~min} / 0.1,0.5 \text { or } 1 \mathrm{mg} \\
\text { i.p./ }-5,-30 \mathrm{~min} / 0.1,0.5 \text { or } 1 \mathrm{mg}\end{array}$ & $\begin{array}{c}\text { IgM 12A1, } \\
\text { dose-dependent }\end{array}$ & $\begin{array}{l}\text { IgMs } 12 \mathrm{~A} 1 \text { and } 13 \mathrm{~F} 1 \\
\text { IgM } 13 \mathrm{~F} 1 \\
\text { IgMs } 12 \mathrm{~A} 1 \text { and } 13 \mathrm{~F} 1\end{array}$ & [12] \\
\hline GXM & $\begin{array}{l}\text { m., preincubation of } \\
\text { yeasts }\end{array}$ & i.p./-24 h/1 mg & $\operatorname{IgG}_{1} *, \operatorname{IgG}_{2 \mathrm{a}} *, \operatorname{IgG}_{2 \mathrm{~b}}$ * & $\mathrm{IgG}_{3}$ * & [16] \\
\hline GXM & m., i.p. & i.p./-1 h/0.5, 5, 50, 100, $1000 \mu \mathrm{g}$ & one hIgM (at $100 \mu \mathrm{g})$ & two hIgM & [14] \\
\hline GXM & m., i.v. & i.v. $/ 10 \mathrm{~d} / 500 \mu \mathrm{g}$ & $\mathrm{chIgG}_{2}$ & & [20] \\
\hline GXM & m., i.v. & i.p./-18 h/0.1-1 mg & recomb. h-IgG ${ }_{2}^{*}$, h-IgG $\operatorname{Ig}_{4} *$ & recomb. h- $\operatorname{IgG}_{1} *$, h-IgG ${ }_{3}^{*}$ & [56] \\
\hline glucosylceramide & m., i.t. & i.p./-24 h/100, 250, $500 \mu \mathrm{g}$ & $\operatorname{IgG}_{2 b}$ at $500 \mu \mathrm{g}$ & $\operatorname{IgG}_{2 \mathrm{~b}}$ at 100 and $250 \mu \mathrm{g}$ & [57] \\
\hline$\beta$-glucan & m., i.v. & i.p./ $/ 2 \mathrm{~h},+1 \mathrm{~d} / 200 \mu \mathrm{g}$ & $\mathrm{IgG}_{2}$ & & [29] \\
\hline GXM M2 motif & m., i.v. & i.p. $/-30 \mathrm{~min} / 500 \mu \mathrm{g}$ & & $\operatorname{IgA}, \operatorname{Ig} M$ & [15] \\
\hline
\end{tabular}


Table 1. Cont.

(B)

\begin{tabular}{|c|c|c|c|c|c|}
\hline Antigen & Infection Model & Application of mAbs $\#$ & Protective & Non-Protective & Reference \\
\hline Hsp90 & m., i.v. & i.v./ $-1 \mathrm{~h} / 740 \mu \mathrm{g}$ & $\operatorname{IgG}$ & & [24] \\
\hline$\beta$-1,2-linked mannotriose & m., i.v. & i.p./-4h, $20 \mathrm{~h} / 125 \mu \mathrm{g}$ & $\operatorname{IgM}$ & & $\begin{array}{l}{[35]} \\
{[35]}\end{array}$ \\
\hline $\begin{array}{c}\text { polysaccharide } \\
\text { mannoprotein } \\
\text { SAP2 }\end{array}$ & $\begin{array}{l}\text { r., i.vg. } \\
\text { r., i.vg. } \\
\text { r., i.vg. }\end{array}$ & $\begin{array}{l}\text { i.v. } / 30 \mathrm{~min} / 100 \mu \mathrm{g} / \mathrm{mL} \\
\text { i.v./30 } \mathrm{min} / 100 \mu \mathrm{g} / \mathrm{mL} \\
\text { i.v. } / 30 \mathrm{~min} / 100 \mu \mathrm{g} / \mathrm{mL}\end{array}$ & $\begin{array}{l}\operatorname{IgM} \\
\operatorname{IgG}_{1}\end{array}$ & $\operatorname{IgG}_{1}$ & [41] \\
\hline$\beta$-1,2-linked mannotriose & m., i.vg. & $\begin{array}{l}\text { i.p./ }-4 \mathrm{~h}, 24 \mathrm{~h} / 35 \mu \mathrm{g}, 10 \mu \mathrm{g} \\
\text { i.vg./ }-4 \mathrm{~h}, 24 \mathrm{~h} / 35 \mu \mathrm{g}, 10 \mu \mathrm{g}\end{array}$ & $\begin{array}{l}\text { IgM } \\
\text { IgM }\end{array}$ & & [34] \\
\hline antiidiotypic KT antibody & r., i.v. & i.v. $/ 0 \mathrm{~h} / 10 \mu \mathrm{g}$ & single chain antibody & & [52] \\
\hline$\beta$-1,2-linked mannotriose & $\begin{array}{l}\text { m., i.v. } \\
\text { m., i.vg. }\end{array}$ & $\begin{array}{l}\text { i.p. } /-4 \mathrm{~h} / 125 \mu \mathrm{g} \\
\text { i.vg./ }-4 \mathrm{~h} / 10 \mu \mathrm{g}\end{array}$ & $\operatorname{IgM}, \operatorname{IgG}_{3}$ & & [36] \\
\hline Hsp90 & m., i.v. & i.v. $/ 2 \mathrm{~h} / 2 \mathrm{mg} / \mathrm{kg}$ & recomb. h-IgG & & [25] \\
\hline PRA1 (mannoprotein 58) & m., i.v. & i.p./ $-2 \mathrm{~h} / 1.8 \mathrm{mg}$ & $\mathrm{IgG}_{1}$ & & [42] \\
\hline$\beta-1,3$-glucan & m., i.v. & i.p. $/-2 \mathrm{~h} / 250 \mu \mathrm{g}$ & $\mathrm{IgG}_{2}$ & & [28] \\
\hline ALS3 mannoprotein & m., i.v. & i.p. $/-4 \mathrm{~h}, 1 \mathrm{~d}, 2 \mathrm{~d} / 200,100,100 \mu \mathrm{g}$ & $\operatorname{IgM}$ & & [43] \\
\hline mannan & m., i.v. & i.p. $/-4 \mathrm{~h} / 63 \mu \mathrm{g}-4 \mathrm{mg}$ & h-IgG 1 & & [37] \\
\hline cell wall carbohydrate & m., i.v. & i.v./ $-2 \mathrm{~h} / 100 \mu \mathrm{g}$ & $\operatorname{IgA}$ & & {$[40]$} \\
\hline$\beta$-1,3-glucan & m., i.v. & i.p./ $-2 \mathrm{~h} / 100 \mu \mathrm{g}$ & $\operatorname{Ig} G_{2} *$ & $\operatorname{Ig} M^{*}$ & [30] \\
\hline Fba peptide & m., i.v. & i.p./ $-4 \mathrm{~h} / 8 \mu \mathrm{g}$ & $\operatorname{IgM}$ & & [58] \\
\hline$\beta$-1,3-glucan & $\begin{array}{l}\text { m., i.v. } \\
\text { r., i.v. }\end{array}$ & $\begin{array}{c}\text { i.p. } /-2 \mathrm{~h} / 100 \mu \mathrm{g} \\
\text { i.v. } / 1 \mathrm{~h}+24 \mathrm{~h}+48 \mathrm{~h} / 50 \mu \mathrm{g}\end{array}$ & $\mathrm{scFv}-\mathrm{Fc}$ & & [31] \\
\hline PNAG & m., keratitis model & i.p. $/ 24 \mathrm{~h} / 200 \mu \mathrm{g}$ & $\mathrm{hIgG}_{1}$ & & [39] \\
\hline Fba peptide & m., i.v. & i.p./ $-4 \mathrm{~h}$, every day/100 $\mu \mathrm{g}$ & $\operatorname{IgM}$ & & \\
\hline Met6 peptide & m., i.v. & i.p./ $-4 \mathrm{~h}$, every day $/ 250 \mu \mathrm{g}$ & $\mathrm{IgG}_{3}$ & & [44] \\
\hline mannan & m., & i.p. $/-4 \mathrm{~h} / 1 \mathrm{mg}$ & $\mathrm{hIgG}_{1}, \mathrm{hIgG}_{3}, \mathrm{hIgG}_{4}$ & $\mathrm{hIgG}_{2}$ & [38] \\
\hline Unknown surface antigen & m., i.v. & i.p./-4 h/1 mg & h- $\operatorname{IgG}_{1}$ & & [49] \\
\hline HYR1 protein & m., i.v. & i.p./-4 h/1 mg & h- $\operatorname{IgG}_{1}$ & & {$[49]$} \\
\hline$\beta$-1,3-glucan & m., i.v. & i.p./-2 h/150 $\mu \mathrm{g}$ & $\mathrm{IgG}_{1}, \mathrm{IgG}_{3}$ & & [32] \\
\hline
\end{tabular}


Table 1. Cont

(C)

\begin{tabular}{|c|c|c|c|c|c|}
\hline Antigen & Infection Model & Application of $\mathrm{mAbs}{ }^{\#}$ & Protective & Non-Protective & Reference \\
\hline \multicolumn{6}{|l|}{ Histoplasma capsulatum } \\
\hline histone $2 \mathrm{~b}$-like protein & m., i.n. & i.p./-2 h/100 $\mu \mathrm{g}$ & $\operatorname{IgM}$ & & [59] \\
\hline Hsp60 & m., i.n. & i.p./-2 h/500 $\mu \mathrm{g}$ & $\operatorname{IgG}_{1}^{* *}, \operatorname{IgG}_{2 \mathrm{a}}$ & $\operatorname{IgG}_{2 b} * *$ & {$[60]$} \\
\hline $70 \mathrm{kDa}$ surface protein & m., i.n. & i.p./-2 h/100-500 $\mu \mathrm{g}$ & & $\operatorname{IgG}_{1}$ & [61] \\
\hline chitin & m., i.n. & i.p./-2 h/10 $\mu \mathrm{g}$ & WGA-Fc $\left(\operatorname{IgG}_{2 \mathrm{a}}\right)$ & & {$[62]$} \\
\hline \multicolumn{6}{|l|}{ Paracoccidioides brasiliensis } \\
\hline glycoprotein of $70 \mathrm{kDa}$ (gp70) & m., i.t. & $\begin{array}{c}\text { i.v. }-3 \mathrm{~d}, 3 \mathrm{~d}, 6 \mathrm{~d}, 9 \mathrm{~d}, 42 \mathrm{~d} / 100 \mu \mathrm{g} \\
\text { each }\end{array}$ & combination of two $\operatorname{IgG}_{1}$ & & [63] \\
\hline 75 kDa secreted phosphatase & m., i.t. & i.v./ $-3 \mathrm{~d} / 100 \mu \mathrm{g}$ & $\operatorname{IgG}, \operatorname{IgM}$ & & {$[64]$} \\
\hline glycoprotein of $43 \mathrm{kDa}$ (gp43) & m., i.t. & i.p./30 d/1 mg & $\mathrm{IgG}_{2 \mathrm{~b}}$ & & {$[65]$} \\
\hline \multirow[t]{2}{*}{ gp43 } & m., i.t. & $\begin{array}{l}\text { i.m./14 d, } 21 \mathrm{~d} / \mathrm{DCs} \text { expressing the } \\
\text { scFv s }\end{array}$ & $\mathrm{scFv}$ & & [66] \\
\hline & m., i.t. & & & & \\
\hline \multicolumn{6}{|l|}{ Paracoccidioides lutzii } \\
\hline Heat shock protein 60 & m., i.t. & not sp./-24 h/1 mg & $\operatorname{IgG}_{2 a}, \operatorname{IgG}_{2 b}$ & & {$[67]$} \\
\hline \multicolumn{6}{|l|}{ Sporothrix schenckii } \\
\hline 70 kDa glycoprotein & m., i.p. & i.p./-24 h, $3 \mathrm{~d}, 6 \mathrm{~d}, 42 \mathrm{~d} / 100 \mu \mathrm{g}$ & $\operatorname{IgG}_{1}$ & & [68] \\
\hline 70 kDa glycoprotein & m., i.p. & i.p. $/ 3 \mathrm{~d}, 10 \mathrm{~d} / 100 \mu \mathrm{g}$ & $\mathrm{IgG}_{1}$ & & [69] \\
\hline $70 \mathrm{kDa}$ glycoprotein & m., i.p. & not sp./3 d/100 $\mu \mathrm{g}$ & $\mathrm{hIgG}_{1}$ & & [70] \\
\hline
\end{tabular}


Table 1. Cont.

(D)

\begin{tabular}{|c|c|c|c|c|c|}
\hline Antigen & Infection Model & Application of mAbs ${ }^{\#}$ & Protective & Non-Protective & Reference \\
\hline \multicolumn{6}{|l|}{ Aspergillus fumigatus } \\
\hline elastase & m., i.n. & i.p. $/ 4 \mathrm{~h} / 50 \mu \mathrm{g}$ & & isotype not sp. & [71] \\
\hline antiidiotypic KT antibody & m., i.n. & i.n./each day/ $2 \times 1 \mu \mathrm{g}$ & rat IgM & & [72] \\
\hline cell wall glycoprotein & m., i.v. & i.v./ $-2 \mathrm{~h} / 50 \mu \mathrm{g}$ & $\operatorname{Ig} G_{1}$ & & [73] \\
\hline unknown cell wall antigen & m., i.n. & i.t./1 h/50 nmol & IgM + alliinase & & [74] \\
\hline galactomannan & m., i.v. & i.p./-15 $\mathrm{min} / 200 \mu \mathrm{g}$ & & $\operatorname{IgM}$ & [75] \\
\hline sialylated oligosaccharides & $\begin{array}{l}\text { m., i.v. } \\
\text { m., i.t. }\end{array}$ & $\begin{array}{l}\text { i.v/0 } \mathrm{min} / 200 \mu \mathrm{g} \\
\text { i.t. } / 0 \mathrm{~min} / 50 \mu \mathrm{g}\end{array}$ & $\operatorname{IgM}$ & & [76] \\
\hline Crf1 protein & r., i.t. & i.t. $/ 4 \mathrm{mg} / \mathrm{kg} / 0 \mathrm{~h}+32 \mathrm{~h}$ & h-IgG 1 & & [77] \\
\hline enolase & m., i.v. & i.v. $/ 2 \mathrm{~h} / 50 \mu \mathrm{g}$ & $\operatorname{IgM}$ & & [78] \\
\hline \multicolumn{6}{|l|}{ Rhizopus delemar } \\
\hline CotH3 protein & m., i.t. & i.p. $/ 48 \mathrm{~h} / 30 \mu \mathrm{g}$ & $\mathrm{IgG}_{1}$ & & [79] \\
\hline $\begin{array}{l}\text { Scedosporium apiospermum } \\
\text { peptidorhamnomannan }\end{array}$ & m., i. t. & i.p./-2 h/250 $\mu \mathrm{g}$ & & $\operatorname{IgG}_{1}$ & [80] \\
\hline
\end{tabular}

In $(\mathbf{A})^{\#}$ : route of application/time point of application relative to the time point of infection/amount of mAbs. *: identical complementarity-determining regions, ${ }^{* *}$ : mapped to the same epitope. $\mathrm{m}=$ mouse, $\mathrm{r}=\mathrm{rat}, \mathrm{h}=$ humanized, $\mathrm{i} . \mathrm{m}=$ intramuscular, i.t. $=$ intratracheally, i.v. $=$ intravenous, i.vg. $=$ intravaginal, not sp. $=$ not specified. chIg $=$ chimeric mouse-human immunoglobulin, KT = killer toxin, PNAG $=\beta-1,6$-poly- $N$-acetyl-D-glucosamine, scFv = single-chain variable fragment, MET6 = 5 methyltetrahydropteroyltriglutamate homocysteine methyltransferase, $\mathrm{Fba}=$ fructose-bisphosphate aldolase. 
In summary, most antibodies that are protective against $C$. albicans or $C$. neoformans infections recognize different glycostructures or surface proteins (Table 1A,B). They are either IgMs or belong to one of the four IgG subclasses. Many protective antibodies were shown to enhance the phagocytic uptake and stimulate the phagolysosomal maturation process (Table 2). In all C. albicans protection experiments that mimic a systemic infection (Table 1B), the yeast form was injected intravenously and in most cases, the antibodies were given prior to infection. Hence, the yeast cells are immediately opsonized and rapidly eliminated by phagocytes in the blood stream. However, this setting does not reflect the normal sequence of events associated with a systemic $C$. albicans infection. The yeast form is often present in the blood stream, but it is normally not the dominant morphotype during infection; hyphae are more abundant and spread in the infected tissue. Whether the protective antibodies described so far are also able to attack C. albicans hyphae and thereby to provide protection in naturally acquired cases of invasive candidiasis remains to be determined. Moreover, for those antibodies that were shown to inhibit hyphal growth in vitro, it is, in most cases, unclear how this growth repression is achieved. More research is clearly required to address these issues.

\section{Protective Antibodies against Dimorphic Fungi}

Dimorphic fungi are a family of six fungal pathogens of humans mainly found in the Americas that show a unique temperature-induced morphological transition: They grow in their filamentous form in the environment but switch to the yeast morphotype during infection. Several studies explored the therapeutic use of antibodies in infections caused by Histoplasma capsulatum, Paracoccidioides brasiliensis, and Sporothrix schenckii. Opsonization of H. capsulatum by an IgM directed to a surface-bound, histone $2 \mathrm{~b}$-like protein promoted the anti-fungal activity of macrophages and resulted in a faster maturation and stronger acidification of their phagosomes [82]. Moreover, administration of this antibody to Histoplasma-infected mice reduced the fungal burden, decreased pulmonary inflammation, and prolonged survival [59]. The heat shock protein $\mathrm{Hsp} 60$ is a major and protective H. capsulatum $\mathrm{T}$ cell antigen. Hsp60-specific antibodies of the $\operatorname{IgG}_{1}$ and $\operatorname{IgG}_{2 a}$, but not of the $\operatorname{IgG}_{2 b}$ subclass reduced the intracellular survival in macrophages, increased phagolysosomal fusion, and prolonged the lives of infected mice [60]. In contrast, an $\mathrm{IgG}_{1}$ directed against a $70 \mathrm{kDa}$ surface protein of $\mathrm{H}$. caspulatum surprisingly increased the intracellular fungal growth and reduced macrophage nitric oxide release in vitro but had no effect on fungal burden or survival in a murine model of infection [61]. Another promising surface protein is the so-called $\mathrm{M}$ antigen of $H$. capsulatum. Opsonization with three $\mathrm{M}$ antigen-specific mAbs (one IgM and two IgG2a) resulted in enhanced phagocytosis and provided full protection in experimental murine histoplasmosis [62].

In a more recent study, Liedke et al. generated a chitin-specific, recombinant antibody-chimera consisting of the chitin-binding domain of the lectin wheat germ agglutinin (WGA) and the Fc portion of a murine $\operatorname{IgG}_{2 \mathrm{a}}$. Only $10 \mu \mathrm{g}$ of WGA-Fc were sufficient to elicit full protection in mice that received a normally lethal dose of $H$. capsulatum [81]. In vitro, WGA-Fc triggered increased phagocytosis and complement deposition and thereby promoted an efficient elimination of the pathogen. Remarkably, WGA-Fc also bound to C. albicans and C. neoformans and sparked an enhanced killing of these pathogens by murine macrophages. Due to this cross-reactivity, WGA-Fc is a promising candidate for the development of a pan-fungal therapeutic [81]. 
In P. brasiliensis, several surface glycoproteins are well-known diagnostic antigens. Passive transfer of mAbs directed against gp70, gp43, and a $75 \mathrm{kDa}$ secreted phosphatase proved to be protective in murine models of infection [63-65] and the same applies to mAbs directed against the heat shock protein 60 of P. lutzii [67]. A different approach was taken by Ferreira et al., who constructed a single-chain variable fragment ( $\mathrm{scFv}$ ) antibody derived from the antiidiotypic antibody 7.B12 [66]. This recombinant construct resembles the internal image of gp43 and thereby served as a substitute for this antigen. When expressed in dendritic cells that were administered to mice, it triggered an enhanced $\mathrm{T}$ cell response, elevated levels of anti-gp43 antibodies, and a dramatic reduction in the number of viable fungi. In a subsequent study, the same group demonstrated that the protective effect could be further enhanced if the scFv molecules were incorporated into poly(lactide-co-glycolic) acid nanoparticles [85].

Another approach that targeted glycoproteins was undertaken with Sporothrix schenckii, a fungus causing chronic subcutaneous mycosis in humans and animals. An IgG raised against a $70 \mathrm{kDa}$ glycoprotein and putative adhesin protected mice from this pathogen when administered either before, during, or even three days after infection [68,69]. A humanized version of this $\operatorname{IgG}_{1}$, given $3 \mathrm{~d}$ post infection, also reduced the fungal burden in the spleens, but not in livers of infected mice [70].

\section{Protective Antibodies against Molds}

Molds are a heterogeneous group of soil-dwelling fungi that share a common lifestyle. Their asexual spores are efficiently spread in the environment, whereas hyphae, their vegetative morphotype, grow in the soil and other habitats. Aspergillus fumigatus is currently the most frequent mold causing severe mycoses, but infections caused by Mucorales and other filamentous fungi are recognized with increasing frequencies. As mentioned above, the filamentous growth of these pathogens during infection represents a particular challenge for the immune system.

In a first study, Frosco et al. analyzed five mAbs specific for a so-called elastase of A. fumigatus that all turned out to be non-protective [71]. Cenci et al. reported a first successful passive immunization experiment with $A$. fumigatus using an antiidiotypic $\mathrm{mAb}$ representing the internal image of yeast killer toxin [72]. This $\mathrm{mAb}$ also inhibited the hyphal growth in in vitro experiments. A similar growth inhibition and protection was later on reported for $2 \mathrm{G} 8$, a mAb specific for $\beta-1,3$-glucan [30]. As for Candida, a corresponding IgM sharing an identical binding site with $2 \mathrm{G} 8$ was non-protective. Another abundant and homogenously distributed glycostructure present on Aspergillus hyphae is galactomannan, but a galactomannan-specific IgM failed to provide protection in mice infected intravenously [75]. These data fit well to the more recent finding that an efficient killing of A. fumigatus hyphae by neutrophils requires antibody-mediated opsonization and activation of Fc $\gamma$-receptors through binding of suitable IgG antibodies [86].

However, other studies provided evidence that $\operatorname{IgM}$ can be protective against A. fumigatus infections. An IgM initially raised against sialyl-lacto-N-tetraose of B group streptococci was shown to recognize a glycoantigen present on A. fumigatus conidia and hyphae. After passive transfer, this $\mathrm{mAb}$ protected mice infected with $A$. fumigatus via the intravenous or intratracheal route [76]. The elimination of $A$. fumigatus conidia and germ tubes by human neutrophils was previously shown to depend on antibody-mediated complement activation [87]; as IgM binds complement factors, protection is most likely established by activation of the classical complement pathway.

Another IgM directed against enolase, an enzyme of the glycolytic pathway, strongly inhibited Aspergillus hyphal growth and prolonged survival of intravenously infected mice [78]. Enolase is one of the so-called moonlighting proteins; it normally resides in the cytoplasm, but some molecules are also found on the cell surface. In vitro experiments showed that the enolase-specific IgM had a striking growth inhibitory activity on Aspergillus hyphae [78], but the underlying mechanisms have not been defined yet. Appel et al. coupled an IgM recognizing a cell wall antigen of $A$. fumigatus to alliinase, an enzyme that converts the harmless garlic compound allicin to alliin, a substance with a broad antifungal activity. If administered together with allicin, this conjugate was able to protect mice from A. fumigatus infections [74]. 
Two further studies analyzed mAbs directed against protein antigens. An IgG 1 recognizing an A. fumigatus cell wall glycoprotein inhibited the growth and even killed A. fumigatus hyphae in vitro. Moreover, this antibody substantially increased the survival times in a murine model of infection [73]. However, due to the lack of follow-up studies, the identity of the antigen and the antifungal mode of action employed by this antibody remained undefined. Chauvin and co-workers generated a humanized $\mathrm{IgG}_{1}$ antibody directed against $\mathrm{Crf1}$, an Aspergillus cell wall enzyme with transglycosylase activity [77]. The Crf1 protein is a prominent $\mathrm{T}$ cell antigen providing striking cross-protection against $A$. fumigatus and C. albicans [88]. The $\mathrm{IgG}_{1}$ antibody detected $\mathrm{Crf1}$ on the hyphal surface, both in vitro and in vivo, inhibited the enzymatic activity of Crf1 and caused a slight growth retardation of A. fumigatus hyphae in vitro. However, when tested in a rat model of infection, this antibody failed to provide protection [77].

Mucorales are a group of non-septated, filamentous molds representing another severe threat for immunocompromised patients. So far, mucormycoses are less frequent than Aspergillus infections, but the numbers have clearly increased in recent years and these rapidly progressing infections are particular difficult to treat [89]. The CotH3 protein of Rhizopus delemar resides on the fungal surface and its interaction with the human glucose-regulated protein (GRP) 78 represents a key event in the hyphal invasion of endothelial cells. Loss of CotH3 results in attenuated virulence [84] and polyclonal CotH3-specific antibodies were shown to block the interaction between CotH3 and GRP78 and thereby reduce invasion of an endothelial layer. These antibodies were furthermore able to inhibit the growth of $R$. delemar in in vitro experiments. The monoclonal anti-CotH3 antibody designated $\mathrm{C} 2$ had similar activities and was successfully used in protection experiments with intratracheally infected mice [79]. Protection was mediated by binding of the Fc part of the $\mathrm{C}_{2} \mathrm{IgG}_{1}$ immunoglobulin to the corresponding Fc $\gamma$-receptor. This interaction triggered enhanced opsonophagocytosis and thereby limited the infection. Application of the antibody in combination with either posaconazole or amphotericin B amplified the protective effect and saved all infected animals [79].

A remarkable example for a mAb causing an exacerbated infection was reported for Scedosporium proliferans. This $\mathrm{IgG}_{1}$ directed to surface-bound peptidorhamnomannan enhanced fungal germination, impaired phagocytosis by macrophages, and reduced the survival time of infected mice [80]. The authors speculated that binding of this $\mathrm{mAb}$ modifies certain activities of the fungus and thereby enhances its virulence. 
Table 2. Activities triggered by selected anti-fungal antibodies in vitro.

\begin{tabular}{|c|c|c|c|c|c|c|}
\hline Antibody & Antigen & Subclass & Fungus & Antifungal Activity & Mode of Action & Reference \\
\hline Mycograb & Hsp90 & rec. $\mathrm{mAb}$ & Candida albicans & stress resistance $\downarrow$ & inhibition of Hsp90 & [25] \\
\hline C7 & ALS3 mannoprotein & $\operatorname{IgM}$ & $\begin{array}{c}\text { Candida albicans } \\
\text { Candia lusitaniae } \\
\text { Cryptococcus neoformans } \\
\text { Aspergillus fumigatus } \\
\text { Scedosporium proliferans }\end{array}$ & $\begin{array}{l}\text { growth inhibition, } \\
\text { adhesion to HEp2 cells } \downarrow\end{array}$ & reduced iron acquisition & $\begin{array}{l}{[46]} \\
{[47]}\end{array}$ \\
\hline $2 \mathrm{G} 8$ & $\beta$-glucan & $\operatorname{Ig} G_{2 b}$ & Candida albicans & growth inhibition & unknown & {$[28,30]$} \\
\hline G5 & cell wall carbohydrate & $\operatorname{Ig} \mathrm{A}$ & Candida albicans & growth inhibition & unknown & [40] \\
\hline $5 \mathrm{H} 5$ & $\beta$-1,3-glucan & $\operatorname{IgG}_{3}$ & $\begin{array}{c}\text { Candida albicans } \\
\text { Aspergillus fumigatus }\end{array}$ & $\begin{array}{c}\text { growth inhibition, } \\
\text { phagocytosis } \uparrow\end{array}$ & $\begin{array}{l}\text { unknown, } \\
\text { osponization }\end{array}$ & [32] \\
\hline M1g1 & mannan & h-IgG & Candida albicans & phagocytosis $\uparrow$, killing $\uparrow$ & complement binding $\uparrow$ & {$[37]$} \\
\hline $2 \mathrm{G} 8 \mathrm{scFv}-\mathrm{Fc}$ & $\beta$-glucan & $\mathrm{scFv}-\mathrm{Fc}$ & Candida albicans & neutrophil mediated killing $\uparrow$ & osponization & [31] \\
\hline 6D2, 11B11 & melanin & $\operatorname{IgM}$ & Cryptococcus neoformans & growth inhibition & unknown & [55] \\
\hline 12A1 & glucuronoxylomannan & $\operatorname{IgM}$ & Cryptococcus neoformans & phagocytosis $\uparrow$ & opzonisation & [12] \\
\hline recomb. 3E5 & GXM & $\mathrm{IgG}_{1}, \mathrm{IgG}_{3}$ & Cryptococcus neoformans & phagocytosis $\uparrow$ & opzonisation & [56] \\
\hline recomb. 3E5 & GXM & $\mathrm{IgG}_{1}, \mathrm{IgG}_{3}$ & Cryptococcus neoformans & phagocytosis $\uparrow$ & opzonisation & [8] \\
\hline $2 \mathrm{G} 8$ & $\beta$-glucan & $\operatorname{IgG}_{2 b}$ & Cryptococcus neoformans & $\begin{array}{c}\text { growth inhibition, } \\
\text { phagocytosis } \uparrow\end{array}$ & unknown, & [29] \\
\hline WGA-Fc & chitin & $\left(\operatorname{IgG}_{2 \mathrm{a}}\right)$ & Cryptococcus neoformans & $\begin{array}{l}\text { growth inhibition, } \\
\text { phagocytosis } \uparrow\end{array}$ & $\begin{array}{c}\text { unknown, } \\
\text { opsonization }\end{array}$ & [81] \\
\hline $4 \mathrm{E} 12$ & Hsp60 & $\operatorname{IgG}_{2 \mathrm{a}}$ & Histoplasma capsulatum & phagocytosis $\uparrow$ & opsonization & [60] \\
\hline $9 \mathrm{C} 7$ & histone $2 \mathrm{~b}$-like protein & $\operatorname{IgM}$ & Histoplasma capsulatum & $\begin{array}{c}\text { phagocytosis } \uparrow, \\
\text { phagosomal maturation } \uparrow\end{array}$ & opsonization & $\begin{array}{l}{[59]} \\
{[82]}\end{array}$ \\
\hline MS112-IIB1 & Crf1, glycosylhydrolase & hum. $\operatorname{IgG}_{1}$ & Aspergillus fumigatus & growth inhibition & inhibition of enzymatic activity & [77] \\
\hline $\mathrm{R}-5$ & enolase & $\operatorname{IgM}$ & Aspergillus fumigatus & growth inhibition & unknown & [78] \\
\hline 7 & catalase B & IgM & Aspergillus fumigatus & growth inhibition & unknown & [83] \\
\hline $2 \mathrm{G} 8$ & $\beta$-1,3-glucan & $\operatorname{IgG}_{2 b}$ & Aspergillus fumigatus & $\begin{array}{l}\text { hyphal growth } \downarrow \text {, adherence to } \\
\text { epithelial cell } \downarrow\end{array}$ & unknown & {$[28,30]$} \\
\hline
\end{tabular}


Table 2. Cont

\begin{tabular}{|c|c|c|c|c|c|c|}
\hline Antibody & Antigen & Subclass & Fungus & Antifungal Activity & Mode of Action & Reference \\
\hline $3 \mathrm{G} 11$ & $\beta-1,3$-glucan & $\operatorname{IgG}_{1}$ & Aspergillus fumigatus & $\begin{array}{c}\text { inhibition of germination, } \\
\text { phagocytosis } \uparrow\end{array}$ & $\begin{array}{c}\text { unknown, } \\
\text { opsonization }\end{array}$ & [32] \\
\hline $\mathrm{C} 1, \mathrm{C} 2, \mathrm{C} 3$ & CotH3 protein & & Rhizopus delemar & $\begin{array}{c}\text { phagocytosis } \uparrow, \\
\text { cytokine response } \uparrow\end{array}$ & opsonization & [84] \\
\hline $3 \mathrm{E}$ & Gp43 & $\operatorname{IgG}_{2 b}$ & Paracoccidioides brasiliensis & phagocytosis $\uparrow, \mathrm{NO} \uparrow$, IFN $\gamma \uparrow$ & opsonization & {$[65]$} \\
\hline 1G6, 5E7C & $75 \mathrm{kDa}$ phosphatase & $\operatorname{IgG}, \operatorname{IgM}$ & Paracoccidioides brasiliensis & $\begin{array}{c}\text { phagocytosis } \uparrow \text {, growth } \\
\text { inhibition }\end{array}$ & opsonization & [64] \\
\hline 7B6, 4E12 & Hsp60 & $\operatorname{IgG}_{2 a}, \operatorname{IgG}_{2 b}$ & Paracoccidioides lutzii & phagocytosis $\uparrow$ & opsonization & [67] \\
\hline P6E7 & Gp70 & & Sporothrix spp. & phagocytosis $\uparrow$ & opsonization & [70] \\
\hline
\end{tabular}




\section{Conclusions}

A large number of studies have provided evidence that the passive transfer of antibodies can protect animals from fungal infections. However, these studies summarized in Table $1 \mathrm{~A}-\mathrm{D}$ are difficult to compare for several reasons: (i) The different pathogenic fungi have a variety of distinct features that are decisive for the respective infections and this can influence the biological impact of therapeutic antibodies, e.g., shedding of capsular polysaccharides by C. neoformans is the reason for ALT. (ii) The biological properties of immunoglobulins differ significantly, e.g., their ability to interact with $F_{c} \gamma$-receptors or to fix complement depend on their (sub)class and the animal species they are derived from. (iii) The routes of experimental infections differ and do not always reflect the natural infection processes. (iv) In a patient, therapeutic antibodies will be given when the infection process has already progressed to a level causing clinical symptoms, but in most studies, antibodies were given prior to infection, which reflects a prophylactic rather than a therapeutic use. (v) The amount of antibody is a critical factor and varies in murine studies at 10-1000 $\mu \mathrm{g}$ per animal. Up to now, only few studies compared different amounts of a given antibody to determine an optimal dosage.

The protective impact of a certain antibody clearly depends on the mechanisms exerted to eliminate the fungal pathogen. The major mechanisms employed by antibodies in order to harm fungal pathogens are schematically depicted in Figure 1. Opsonization can result in an efficient elimination of small and predominantly unicellular fungi, and it can boost other antimicrobial effector mechanisms, e.g., by attraction and activation of neutrophils. Another mechanism reported by several studies is the antibody-mediated inhibition of fungal growth, but our knowledge about suitable antigen/antibody combinations and the underlying molecular processes is still in its infancy. Antibodies with a direct and deleterious impact on the fungus represent a particularly promising option, since they act independently of other immune molecules and cells, which is an obvious advantage in a severely immunocompromised host. Antibodies may inhibit the biological function of surface proteins and thereby reduce the ability of the target cell to adapt to certain stress situations (e.g., anti Hsp90 mAbs). Alternatively, antibodies may interfere with transport channels, uptake systems, or proteins that are required for the maintenance and reorganization of the cell wall. Anti-idiotypic antibodies employ a direct antifungal mode of action or may alternatively act as a substitute for the original antigen; this can boost an immune response directed towards this antigen and thereby provide protection. Secreted proteins are in principle attractive targets, but up to now, only one mAb specific for C. albicans Sap2 was shown to be protective in models of Candida vaginitis. Antibodies against conserved cell wall glycostructures can bind to a range of fungal pathogens. The use of chimeric molecules, such as the lectin domain-containing WGA-Fc construct, can extend the repertoire of suitable molecules, but a potential drawback of this strategy is that the lectin domain may trigger a strong immune response that could prevent a prolonged application.

The serious threat posed by invasive fungal infections is a persisting problem and therefore new therapeutic options are clearly required. Monoclonal antibodies are now widely used in modern medicine, but we are just beginning to explore their potential in the context of fungal infections. The data available so far that are summarized here strongly suggest that mAbs are promising prophylactic tools, but further studies are clearly required to determine whether the same applies to a therapeutic use in the setting of an already established fungal infection. 


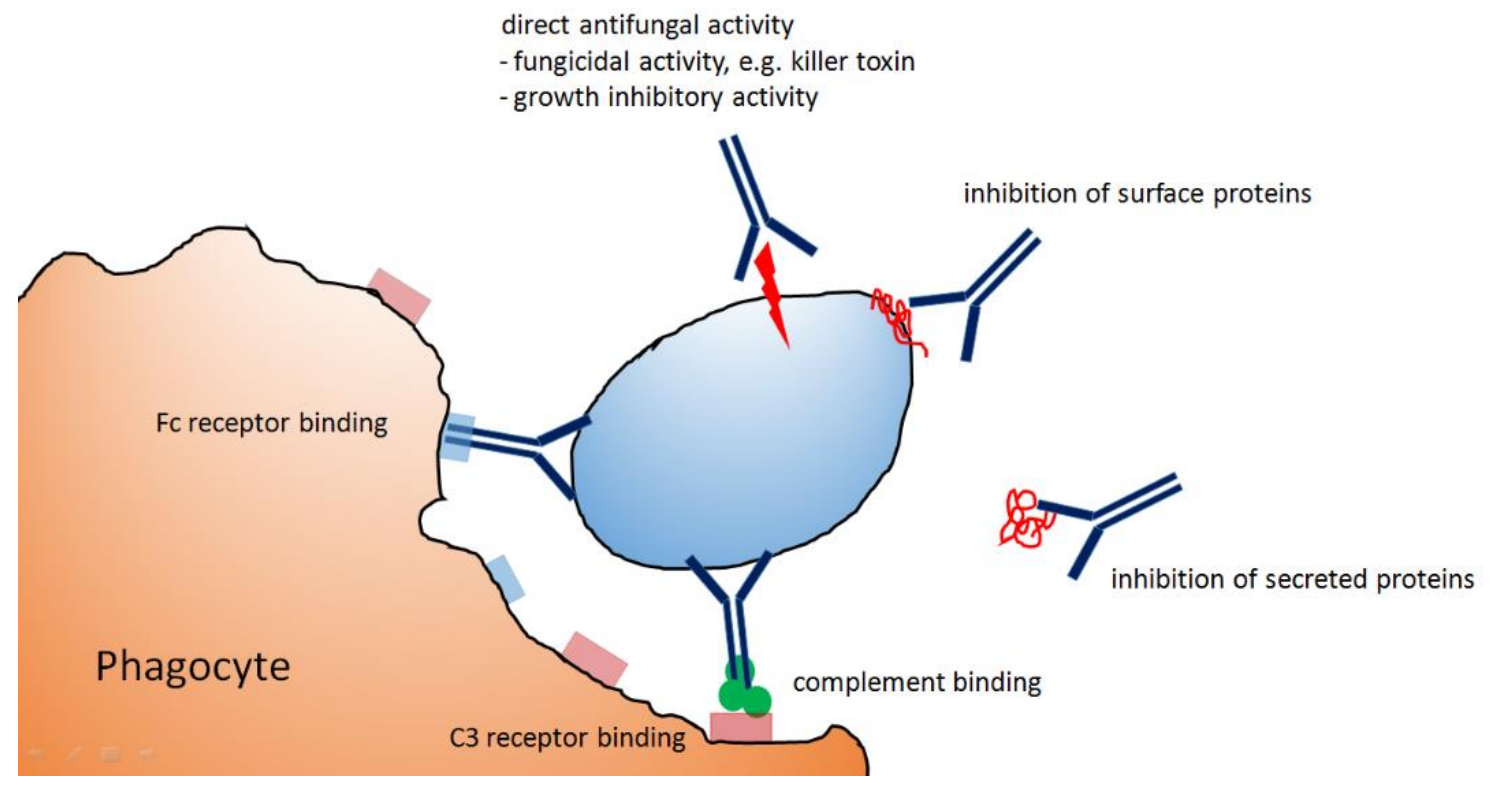

Figure 1. Different modes of actions employed by antibodies to inhibit or kill fungal pathogens.

Author Contributions: S.U. and F.E. wrote the manuscript. All authors have read and agreed to the published version of the manuscript.

Funding: Brigitte and Wolfram Gedek Foundation, Ismaning, Germany.

Conflicts of Interest: The authors declare no conflict of interest.

\section{References}

1. Brown, G.D.; Denning, D.W.; Gow, N.A.; Levitz, S.M.; Netea, M.G.; White, T.C. Hidden killers: Human fungal infections. Sci. Transl. Med. 2012, 4, 165rv13. [CrossRef] [PubMed]

2. Aderem, A.; Underhill, D.M. Mechanisms of phagocytosis in macrophages. Annu. Rev. Immunol. 1999, 17, 593-623. [CrossRef] [PubMed]

3. Bowen, A.; Wear, M.P.; Cordero, R.J.; Oscarson, S.; Casadevall, A. A Monoclonal Antibody to Cryptococcus neoformans Glucuronoxylomannan Manifests Hydrolytic Activity for Both Peptides and Polysaccharides. J. Biol. Chem. 2017, 292, 417-434. [CrossRef] [PubMed]

4. Dromer, F.; Charreire, J.; Contrepois, A.; Carbon, C.; Yeni, P. Protection of mice against experimental cryptococcosis by anti-Cryptococcus neoformans monoclonal antibody. Infect. Immun. 1987, 55, 749-752. [CrossRef] [PubMed]

5. Fleuridor, R.; Zhong, Z.; Pirofski, L. A human IgM monoclonal antibody prolongs survival of mice with lethal cryptococcosis. J. Infect. Dis. 1998, 178, 1213-1216. [CrossRef] [PubMed]

6. Yuan, R.; Clynes, R.; Oh, J.; Ravetch, J.V.; Scharff, M.D. Antibody-mediated modulation of Cryptococcus neoformans infection is dependent on distinct Fc receptor functions and IgG subclasses. J. Exp. Med. 1998, 187, 641-648. [CrossRef]

7. Mukherjee, J.; Scharff, M.D.; Casadevall, A. Protective murine monoclonal antibodies to Cryptococcus neoformans. Infect. Immun. 1992, 60, 4534-4541. [CrossRef]

8. Saylor, C.A.; Dadachova, E.; Casadevall, A. Murine IgG1 and IgG3 isotype switch variants promote phagocytosis of Cryptococcus neoformans through different receptors1. J. Immunol. 2010, 184, 336-343. [CrossRef]

9. Yuan, R.R.; Casadevall, A.; Oh, J.; Scharff, M.D. T cells cooperate with passive antibody to modify Cryptococcus neoformans infection in mice. Proc. Natl. Acad. Sci. USA 1997, 94, 2483-2488. [CrossRef]

10. Yuan, R.; Casadevall, A.; Spira, G.; Scharff, M.D. Isotype switching from IgG3 to IgG1 converts a nonprotective murine antibody to Cryptococcus neoformans into a protective antibody. J. Immunol. 1995, 154, 1810-1816. 
11. Rivera, J.; Casadevall, A. Mouse genetic background is a major determinant of isotype-related differences for antibody-mediated protective efficacy against Cryptococcus neoformans. J. Immunol. 2005, 174, 8017-8026. [CrossRef] [PubMed]

12. Taborda, C.P.; Casadevall, A. Immunoglobulin M efficacy against Cryptococcus neoformans: Mechanism, dose dependence, and prozone-like effects in passive protection experiments. J. Immunol. 2001, 166, 2100-2107. [CrossRef] [PubMed]

13. Mukherjee, J.; Nussbaum, G.; Scharff, M.D.; Casadevall, A. Protective and nonprotective monoclonal antibodies to Cryptococcus neoformans originating from one B cell. J. Exp. Med. 1995, 181, 405-409. [CrossRef]

14. Maitta, R.W.; Datta, K.; Chang, Q.; Luo, R.X.; Witover, B.; Subramaniam, K.; Pirofski, L.A. Protective and nonprotective human immunoglobulin $\mathrm{M}$ monoclonal antibodies to Cryptococcus neoformans glucuronoxylomannan manifest different specificities and gene use profiles. Infect. Immun. 2004, 72, 4810-4818. [CrossRef]

15. Nakouzi, A.; Zhang, T.; Oscarson, S.; Casadevall, A. The common Cryptococcus neoformans glucuronoxylomannan M2 motif elicits non-protective antibodies. Vaccine 2009, 27, 3513-3518. [CrossRef]

16. Shapiro, S.; Beenhouwer, D.O.; Feldmesser, M.; Taborda, C.; Carroll, M.C.; Casadevall, A. Immunoglobulin $\mathrm{G}$ monoclonal antibodies to Cryptococcus neoformans protect mice deficient in complement component C3. Infect. Immun. 2002, 70, 2598-2604. [CrossRef]

17. Taborda, C.P.; Rivera, J.; Zaragoza, O.; Casadevall, A. More is not necessarily better: Prozone-like effects in passive immunization with IgG. J. Immunol. 2003, 170, 3621-3630. [CrossRef]

18. Savoy, A.C.; Lupan, D.M.; Manalo, P.B.; Roberts, J.S.; Schlageter, A.M.; Weinhold, L.C.; Kozel, T.R. Acute lethal toxicity following passive immunization for treatment of murine cryptococcosis. Infect. Immun. 1997, 65, 1800-1807. [CrossRef]

19. Lendvai, N.; Casadevall, A. Monoclonal antibody-mediated toxicity in Cryptococcus neoformans infection: Mechanism and relationship to antibody isotype. J. Infect. Dis. 1999, 180, 791-801. [CrossRef]

20. Westin Kwon, K.; Lendvai, N.; Morrison, S.; Trinh, K.R.; Casadevall, A. Biological activity of a mouse-human chimeric immunoglobulin G2 antibody to Cryptococcus neoformans polysaccharide. Clin. Diagn. Lab. Immunol. 2002, 9, 201-204. [CrossRef]

21. Matthews, R.C.; Burnie, J.P.; Tabaqchali, S. Isolation of immunodominant antigens from sera of patients with systemic candidiasis and characterization of serological response to Candida albicans. J. Clin. Microbiol. 1987, 25, 230-237. [CrossRef]

22. Matthews, R.; Burnie, J. Cloning of a DNA sequence encoding a major fragment of the 47 kilodalton stress protein homologue of Candida albicans. FEMS Microbiol. Lett. 1989, 51, 25-30. [CrossRef]

23. O'Meara, T.R.; Robbins, N.; Cowen, L.E. The Hsp90 Chaperone Network Modulates Candida Virulence Traits. Trends Microbiol. 2017, 25, 809-819. [CrossRef]

24. Matthews, R.C.; Burnie, J.P.; Howat, D.; Rowland, T.; Walton, F. Autoantibody to heat-shock protein 90 can mediate protection against systemic candidosis. Immunology 1991, 74, 20-24.

25. Matthews, R.C.; Rigg, G.; Hodgetts, S.; Carter, T.; Chapman, C.; Gregory, C.; Illidge, C.; Burnie, J. Preclinical assessment of the efficacy of mycograb, a human recombinant antibody against fungal HSP90. Antimicrob. Agents Chemother. 2003, 47, 2208-2216. [CrossRef]

26. Burt, E.T.; Daly, R.; Hoganson, D.; Tsirulnikov, Y.; Essmann, M.; Larsen, B. Isolation and partial characterization of Hsp90 from Candida albicans. Ann. Clin. Lab. Sci. 2003, 33, 86-93.

27. Pachl, J.; Svoboda, P.; Jacobs, F.; Vandewoude, K.; van der Hoven, B.; Spronk, P.; Masterson, G.; Malbrain, M.; Aoun, M.; Garbino, J.; et al. A randomized, blinded, multicenter trial of lipid-associated amphotericin B alone versus in combination with an antibody-based inhibitor of heat shock protein 90 in patients with invasive candidiasis. Clin. Infect. Dis. 2006, 42, 1404-1413. [CrossRef]

28. Torosantucci, A.; Bromuro, C.; Chiani, P.; De Bernardis, F.; Berti, F.; Galli, C.; Norelli, F.; Bellucci, C.; Polonelli, L.; Costantino, P.; et al. A novel glyco-conjugate vaccine against fungal pathogens. J. Exp. Med. 2005, 202, 597-606. [CrossRef]

29. Rachini, A.; Pietrella, D.; Lupo, P.; Torosantucci, A.; Chiani, P.; Bromuro, C.; Proietti, C.; Bistoni, F.; Cassone, A.; Vecchiarelli, A. An anti-beta-glucan monoclonal antibody inhibits growth and capsule formation of Cryptococcus neoformans in vitro and exerts therapeutic, anticryptococcal activity in vivo. Infect. Immun. 2007, 75, 5085-5094. [CrossRef] 
30. Torosantucci, A.; Chiani, P.; Bromuro, C.; De Bernardis, F.; Palma, A.S.; Liu, Y.; Mignogna, G.; Maras, B.; Colone, M.; Stringaro, A.; et al. Protection by anti-beta-glucan antibodies is associated with restricted beta-1,3 glucan binding specificity and inhibition of fungal growth and adherence. PLoS ONE 2009, 4, e5392. [CrossRef]

31. Capodicasa, C.; Chiani, P.; Bromuro, C.; De Bernardis, F.; Catellani, M.; Palma, A.S.; Liu, Y.; Feizi, T.; Cassone, A.; Benvenuto, E.; et al. Plant production of anti- $\beta$-glucan antibodies for immunotherapy of fungal infections in humans. Plant. Biotechnol. J. 2011, 9, 776-787. [CrossRef]

32. Matveev, A.L.; Krylov, V.B.; Khlusevich, Y.A.; Baykov, I.K.; Yashunsky, D.V.; Emelyanova, L.A.; Tsvetkov, Y.E.; Karelin, A.A.; Bardashova, A.V.; Wong, S.S.W.; et al. Novel mouse monoclonal antibodies specifically recognizing $\beta$-(1 $\rightarrow 3)$-D-glucan antigen. PLoS ONE 2019, 14, e0215535. [CrossRef]

33. Han, Y.; Kanbe, T.; Cherniak, R.; Cutler, J.E. Biochemical characterization of Candida albicans epitopes that can elicit protective and nonprotective antibodies. Infect. Immun. 1997, 65, 4100-4107. [CrossRef]

34. Han, Y.; Morrison, R.P.; Cutler, J.E. A vaccine and monoclonal antibodies that enhance mouse resistance to Candida albicans vaginal infection. Infect. Immun. 1998, 66, 5771-5776. [CrossRef]

35. Han, Y.; Cutler, J.E. Antibody response that protects against disseminated candidiasis. Infect. Immun. 1995, 63, 2714-2719. [CrossRef]

36. Han, Y.; Riesselman, M.H.; Cutler, J.E. Protection against candidiasis by an immunoglobulin G3 (IgG3) monoclonal antibody specific for the same mannotriose as an IgM protective antibody. Infect. Immun. 2000, 68, 1649-1654. [CrossRef]

37. Zhang, M.X.; Bohlman, M.C.; Itatani, C.; Burton, D.R.; Parren, P.W.; St Jeor, S.C.; Kozel, T.R. Human recombinant antimannan immunoglobulin G1 antibody confers resistance to hematogenously disseminated candidiasis in mice. Infect. Immun. 2006, 74, 362-369. [CrossRef]

38. Nishiya, C.T.; Boxx, G.M.; Robison, K.; Itatani, C.; Kozel, T.R.; Zhang, M.X. Influence of IgG Subclass on Human Antimannan Antibody-Mediated Resistance to Hematogenously Disseminated Candidiasis in Mice. Infect. Immun. 2015, 84, 386-394. [CrossRef]

39. Cywes-Bentley, C.; Skurnik, D.; Zaidi, T.; Roux, D.; Deoliveira, R.B.; Garrett, W.S.; Lu, X.; O’Malley, J.; Kinzel, K.; Zaidi, T.; et al. Antibody to a conserved antigenic target is protective against diverse prokaryotic and eukaryotic pathogens. Proc. Natl. Acad. Sci. USA 2013, 110, E2209-E2218. [CrossRef]

40. Kavishwar, A.; Shukla, P.K. Candidacidal activity of a monoclonal antibody that binds with glycosyl moieties of proteins of Candida albicans. Med. Mycol. 2006, 44, 159-167. [CrossRef]

41. De Bernardis, F.; Boccanera, M.; Adriani, D.; Spreghini, E.; Santoni, G.; Cassone, A. Protective role of antimannan and anti-aspartyl proteinase antibodies in an experimental model of Candida albicans vaginitis in rats. Infect. Immun. 1997, 65, 3399-3405. [CrossRef] [PubMed]

42. Viudes, A.; Lazzell, A.; Perea, S.; Kirkpatrick, W.R.; Peman, J.; Patterson, T.F.; Martinez, J.P.; López-Ribot, J.L. The C-terminal antibody binding domain of Candida albicans mp58 represents a protective epitope during candidiasis. FEMS Microbiol. Lett. 2004, 232, 133-138. [CrossRef]

43. Sevilla, M.J.; Robledo, B.; Rementeria, A.; Moragues, M.D.; Pontón, J. A fungicidal monoclonal antibody protects against murine invasive candidiasis. Infect. Immun. 2006, 74, 3042-3045. [CrossRef]

44. Xin, H. Active immunizations with peptide-DC vaccines and passive transfer with antibodies protect neutropenic mice against disseminated candidiasis. Vaccine 2016, 34, 245-251. [CrossRef]

45. Liu, Y.; Filler, S.G. Candida albicans, Als3., a multifunctional adhesin and invasin. Eukaryot. Cell 2011, 10, 168-173. [CrossRef]

46. Moragues, M.D.; Omaetxebarria, M.J.; Elguezabal, N.; Sevilla, M.J.; Conti, S.; Polonelli, L.; Pontón, J. A monoclonal antibody directed against a Candida albicans cell wall mannoprotein exerts three anti-C. albicans activities. Infect. Immun. 2003, 71, 5273-5279. [CrossRef]

47. Brena, S.; Cabezas-Olcoz, J.; Moragues, M.D.; Fernández de Larrinoa, I.; Domínguez, A.; Quindós, G.; Pontón, J. Fungicidal monoclonal antibody C7 interferes with iron acquisition in Candida albicans. Antimicrob. Agents Chemother. 2011, 55, 3156-3163. [CrossRef]

48. Luo, G.; Ibrahim, A.S.; French, S.W.; Edwards, J.E., Jr.; Fu, Y. Active and passive immunization with rHyr1p-N protects mice against hematogenously disseminated candidiasis. PLoS ONE 2011, 6, e25909. [CrossRef]

49. Rudkin, F.M.; Raziunaite, I.; Workman, H.; Essono, S.; Belmonte, R.; MacCallum, D.M.; Johnson, E.M.; Silva, L.M.; Palma, A.S.; Feizi, T.; et al. Single human B cell-derived monoclonal anti-Candida antibodies enhance phagocytosis and protect against disseminated candidiasis. Nat. Commun. 2018, 9, 5288. [CrossRef] 
50. Schaller, M.; Bein, M.; Korting, H.C.; Baur, S.; Hamm, G.; Monod, M.; Beinhauer, S.; Hube, B. The secreted aspartyl proteinases Sap1 and Sap2 cause tissue damage in an in vitro model of vaginal candidiasis based on reconstituted human vaginal epithelium. Infect. Immun. 2003, 71, 3227-3234. [CrossRef]

51. Schmitt, M.J.; Breinig, F. Yeast viral killer toxins: Lethality and self-protection. Nature Rev. Microbiol. 2006, 4, 212-221. [CrossRef]

52. Magliani, W.; Conti, S.; de Bernardis, F.; Gerloni, M.; Bertolotti, D.; Mozzoni, P.; Cassone, A.; Polonelli, L. Therapeutic potential of antiidiotypic single chain antibodies with yeast killer toxin activity. Nat. Biotechnol. 1997, 15, 155-158. [CrossRef]

53. Sanford, J.E.; Lupan, D.M.; Schlageter, A.M.; Kozel, T.R. Passive immunization against Cryptococcus neoformans with an isotype-switch family of monoclonal antibodies reactive with cryptococcal polysaccharide. Infect. Immun. 1990, 58, 1919-1923. [CrossRef]

54. Zebedee, S.L.; Koduri, R.K.; Mukherjee, J.; Mukherjee, S.; Lee, S.; Sauer, D.F.; Scharff, M.D.; Casadevall, A. Mouse-human immunoglobulin G1 chimeric antibodies with activities against Cryptococcus neoformans. Antimicrob. Agents Chemother. 1994, 38, 1507-1514. [CrossRef]

55. Rosas, A.L.; Nosanchuk, J.D.; Casadevall, A. Passive immunization with melanin-binding monoclonal antibodies prolongs survival of mice with lethal Cryptococcus neoformans infection. Infect. Immun. 2001, 69, 3410-3412. [CrossRef] [PubMed]

56. Beenhouwer, D.O.; Yoo, E.M.; Lai, C.W.; Rocha, M.A.; Morrison, S.L. Human immunoglobulin G2 (IgG2) and IgG4, but not IgG1 or IgG3, protect mice against Cryptococcus neoformans infection. Infect. Immun. 2007, 75, 1424-1435. [CrossRef] [PubMed]

57. Rodrigues, M.L.; Shi, L.; Barreto-Bergter, E.; Nimrichter, L.; Farias, S.E.; Rodrigues, E.G.; Travassos, L.R.; Nosanchuk, J.D. Monoclonal antibody to fungal glucosylceramide protects mice against lethal Cryptococcus neoformans infection. Clin. Vaccine Immunol. 2007, 14, 1372-1376. [CrossRef]

58. Xin, H.; Cutler, J.E. Vaccine and monoclonal antibody that enhance mouse resistance to candidiasis. Clin. Vaccine Immunol. 2011, 18, 1656-1667. [CrossRef]

59. Nosanchuk, J.D.; Steenbergen, J.N.; Shi, L.; Deepe, G.S., Jr.; Casadevall, A. Antibodies to a cell surface histone-like protein protect against Histoplasma capsulatum. J. Clin. Investig. 2003, 112, 1164-1175. [CrossRef]

60. Guimarães, A.J.; Frases, S.; Gomez, F.J.; Zancopé-Oliveira, R.M.; Nosanchuk, J.D. Monoclonal antibodies to heat shock protein 60 alter the pathogenesis of Histoplasma capsulatum. Infect. Immun. 2009, 77, 1357-1367. [CrossRef]

61. Lopes, L.C.; Guimarães, A.J.; de Cerqueira, M.D.; Gómez, B.L.; Nosanchuk, J.D. A histoplasma capsulatum-specific IgG1 isotype monoclonal antibody, H1C, to a 70-kilodalton cell surface protein is not protective in murine histoplasmosis. Clin. Vaccine Immunol. 2010, 17, 1155-1158. [CrossRef] [PubMed]

62. Nosanchuk, J.D.; Zancopé-Oliveira, R.M.; Hamilton, A.J.; Guimarães, A.J. Antibody therapy for histoplasmosis. Front. Microbiol. 2012, 3, 21. [CrossRef] [PubMed]

63. De Mattos Grosso, D.; de Almeida, S.R.; Mariano, M.; Lopes, J.D. Characterization of gp70 and anti-gp70 monoclonal antibodies in Paracoccidioides brasiliensis pathogenesis. Infect. Immun. 2003, 71, 6534-6542. [CrossRef] [PubMed]

64. Xander, P.; Vigna, A.F.; Feitosa, L.; dos, S.; Pugliese, L.; Bailao, A.M.; Soares, C.M.; Mortara, R.A.; Mariano, M.; Lopes, J.D. A surface 75-kDa protein with acid phosphatase activity recognized by monoclonal antibodies that inhibit Paracoccidioides brasiliensis growth. Microbes Infect. 2007, 9, 1484-1492. [CrossRef] [PubMed]

65. Buissa-Filho, R.; Puccia, R.; Marques, A.F.; Pinto, F.A.; Muñoz, J.E.; Nosanchuk, J.D.; Travassos, L.R.; Taborda, C.P. The monoclonal antibody against the major diagnostic antigen of Paracoccidioides brasiliensis mediates immune protection in infected BALB/c mice challenged intratracheally with the fungus. Infect. Immun. 2008, 76, 3321-3328. [CrossRef]

66. Ferreira, K.S.; Maranhão, A.Q.; Garcia, M.C.; Brígido, M.M.; Santos, S.S.; Lopes, J.D.; Almeida, S.R. Dendritic cells transfected with $\mathrm{scFv}$ from Mab 7.B12 mimicking original antigen gp43 induces protection against experimental Paracoccidioidomycosis. PLoS ONE 2011, 6, e15935. [CrossRef]

67. Thomaz, L.; Nosanchuk, J.D.; Rossi, D.C.; Travassos, L.R.; Taborda, C.P. Monoclonal antibodies to heat shock protein 60 induce a protective immune response against experimental Paracoccidioides lutzii. Microbes Infect. 2014, 16, 788-795. [CrossRef] 
68. Nascimento, R.C.; Espindola, N.M.; Castro, R.A.; Teixeira, P.A.C.; Penha, C.V.L.Y.; Lopes-Bezerra, L.M.; Almeida, S.R. Passive immunization with monoclonal antibody against a 70-kDa putative adhesin of Sporothrix schenckii induces protection in murine sporotrichosis. Eur. J. Immunol. 2008, 38, 3080-3089. [CrossRef]

69. De Almeida, J.R.; Kaihami, G.H.; Jannuzzi, G.P.; de Almeida, S.R. Therapeutic vaccine using a monoclonal antibody against a 70-kDa glycoprotein in mice infected with highly virulent Sporothrix schenckii and Sporothrix brasiliensis. Med. Mycol. 2015, 53, 42-50. [CrossRef]

70. De Almeida, J.R.; Santiago, K.L.; Kaihami, G.H.; Maranhão, A.Q.; de Macedo Brígido, M.; de Almeida, S.R. The Efficacy of Humanized Antibody against the Sporothrix Antigen, gp70, in Promoting Phagocytosis and Reducing Disease Burden. Front. Microbiol. 2017, 8, 345. [CrossRef]

71. Frosco, M.B.; Chase, T., Jr.; Macmillan, J.D. The effect of elastase-specific monoclonal and polyclonal antibodies on the virulence of Aspergillus fumigatus in immunocompromised mice. Mycopathologia 1994, 125, 65-76. [CrossRef] [PubMed]

72. Cenci, E.; Mencacci, A.; Spreca, A.; Montagnoli, C.; Bacci, A.; Perruccio, K.; Velardi, A.; Magliani, W.; Conti, S.; Polonelli, L.; et al. Protection of killer antiidiotypic antibodies against early invasive aspergillosis in a murine model of allogeneic T-cell-depleted bone marrow transplantation. Infect. Immun. 2002, 70, 2375-2382. [CrossRef] [PubMed]

73. Chaturvedi, A.K.; Kavishwar, A.; Shiva Keshava, G.B.; Shukla, P.K. Monoclonal immunoglobulin G1 directed against Aspergillus fumigatus cell wall glycoprotein protects against experimental murine aspergillosis. Clin. Diagn. Lab. Immunol. 2005, 12, 1063-1068. [CrossRef] [PubMed]

74. Appel, E.; Vallon-Eberhard, A.; Rabinkov, A.; Brenner, O.; Shin, I.; Sasson, K.; Shadkchan, Y.; Osherov, N.; Jung, S.; Mirelman, D. Therapy of murine pulmonary aspergillosis with antibody-alliinase conjugates and alliin. Antimicrob. Agents Chemother. 2010, 54, 898-906. [CrossRef] [PubMed]

75. Heesemann, L.; Kotz, A.; Echtenacher, B.; Broniszewska, M.; Routier, F.; Hoffmann, P.; Ebel, F. Studies on galactofuranose-containing glycostructures of the pathogenic mold Aspergillus fumigatus. Int. J. Med. Microbiol. 2011, 321, 523-530. [CrossRef] [PubMed]

76. Wharton, R.E.; Stefanov, E.K.; King, R.G.; Kearney, J.F. Antibodies generated against Streptococci protect in a mouse model of disseminated aspergillosis. J. Immunol. 2015, 194, 4387-4396. [CrossRef]

77. Chauvin, D.; Hust, M.; Schütte, M.; Chesnay, A.; Parent, C.; Moreira, G.M.S.G.; Arroyo, J.; Sanz, A.B.; Pugnière, M.; Martineau, P.; et al. Targeting Aspergillus fumigatus Crf Transglycosylases With Neutralizing Antibody Is Relevant but Not Sufficient to Erase Fungal Burden in a Neutropenic Rat Model. Front. Microbiol. 2019, 10, 600. [CrossRef]

78. Yadav, R.K.; Shukla, P.K. A novel monoclonal antibody against enolase antigen of Aspergillus fumigatus protects experimental aspergillosis in mice. FEMS Microbiol. Lett. 2019, 366, fnz015. [CrossRef]

79. Gebremariam, T.; Alkhazraji, S.; Soliman, S.S.M.; Gu, Y.; Jeon, H.H.; Zhang, L.; French, S.W.; Stevens, D.A.; Edwards, J.E., Jr.; Filler, S.G.; et al. Anti-CotH3 antibodies protect mice from mucormycosis by prevention of invasion and augmenting opsonophagocytosis. Sci. Adv. 2019, 5, eaaw1327. [CrossRef]

80. Lopes, L.C.; Rollin-Pinheiro, R.; Guimarães, A.J.; Bittencourt, V.C.; Martinez, L.R.; Koba, W.; Farias, S.E.; Nosanchuk, J.D.; Barreto-Bergter, E. Monoclonal antibodies against peptidorhamnomannans of Scedosporium apiospermum enhance the pathogenicity of the fungus. PLoS Negl. Trop. Dis. 2010, 4, e853. [CrossRef]

81. Liedke, S.C.; Miranda, D.Z.; Gomes, K.X.; Gonçalves, J.L.S.; Frases, S.; Nosanchuk, J.D.; Rodrigues, M.L.; Nimrichter, L.; Peralta, J.M.; Guimarães, A.J. Characterization of the antifungal functions of a WGA-Fc (IgG2a) fusion protein binding to cell wall chitin oligomers. Sci. Rep. 2017, 7, 12187. [CrossRef] [PubMed]

82. Shi, L.; Albuquerque, P.C.; Lazar-Molnar, E.; Wang, X.; Santambrogio, L.; Gácser, A.; Nosanchuk, J.D. A monoclonal antibody to Histoplasma capsulatum alters the intracellular fate of the fungus in murine macrophages. Eukaryot. Cell 2008, 7, 1109-1117. [CrossRef] [PubMed]

83. Chaturvedi, A.K.; Kumar, R.; Kumar, A.; Shukla, P.K. A monoclonal IgM directed against immunodominant catalase B of cell wall of Aspergillus fumigatus exerts anti-A. fumigatus activities. Mycoses 2009, 52, 524-533. [CrossRef] [PubMed]

84. Gebremariam, T.; Liu, M.; Luo, G.; Bruno, V.; Phan, Q.T.; Waring, A.J.; Edwards, J.E.; Filler, S.G.; Yeaman, M.R.; Ibrahim, A.S. CotH3 mediates fungal invasion of host cells during mucormycosis. J. Clin. Investig. 2014, 124, 237-250. [CrossRef] [PubMed] 
85. Jannuzzi, G.P.; Souza, N.A.; Françoso, K.S.; Pereira, R.H.; Santos, R.P.; Kaihami, G.H.; Almeida, J.R.F.; Batista, W.L.; Amaral, A.C.; Maranhão, A.Q.; et al. Therapeutic treatment with scFv-PLGA nanoparticles decreases pulmonary fungal load in a murine model of paracoccidioidomycosis. Microbes Infect. 2018, 20, 48-56. [CrossRef]

86. Gazendam, R.P.; van Hamme, J.L.; Tool, A.T.; Hoogenboezem, M.; van den Berg, J.M.; Prins, J.M.; Vitkov, L.; van de Veerdonk, F.L.; van den Berg, T.K.; Roos, D.; et al. Human Neutrophils Use Different Mechanisms to Kill Aspergillus fumigatus Conidia and Hyphae: Evidence from Phagocyte Defects. J. Immunol. 2016, 196, 1272-1283. [CrossRef]

87. Braem, S.G.; Rooijakkers, S.H.; van Kessel, K.P.; de Cock, H.; Wösten, H.A.; van Strijp, J.A.; Haas, P.J. Effective Neutrophil Phagocytosis of Aspergillus fumigatus Is Mediated by Classical Pathway Complement Activation. J. Innate Immun. 2015, 7, 364-374. [CrossRef]

88. Stuehler, C.; Khanna, N.; Bozza, S.; Zelante, T.; Moretti, S.; Kruhm, M.; Lurati, S.; Conrad, B.; Worschech, E.; Stevanović, S.; et al. Cross-protective TH1 immunity against Aspergillus fumigatus and Candida albicans. Blood 2011, 117, 5881-5891. [CrossRef]

89. Farmakiotis, D.; Kontoyiannis, D.P. Mucormycoses. Infect. Dis. Clin. N. Am. 2016, 30, 143-163. [CrossRef]

(C) 2020 by the authors. Licensee MDPI, Basel, Switzerland. This article is an open access article distributed under the terms and conditions of the Creative Commons Attribution (CC BY) license (http://creativecommons.org/licenses/by/4.0/). 